\section{International Scientific Journal Theoretical \& Applied Science}

\author{
p-ISSN: 2308-4944 (print) e-ISSN: 2409-0085 (online) \\ Year: 2015 Issue: 09 Volume: 29
}

Published: $30.09 .2015 \quad$ http://T-Science.org
Yulia Viktorovna Sviatiuk

PhD in Philology, Associate Professor

Foreign languages department

Kyiv Taras Shevchenko National University,

Ukraine

sviatiuk@ukr.net

SECTION 29. Literature, Folklore, Translation

Studies.

\title{
BUSINESS CORRESPONDENCE STYLE AND FORMAT
}

Abstract: The research provides an insight into effective business letter writing. The major types of business correspondence are singled out.

The peculiarities and specific features of formal style, language and grammar usage are discussed.

The study presents essential rules of business letter writing and analyses the structure and the main components constituting business letters, as well as conventional formats of business correspondence.

Recommendations on effective business letter writing, formal style and language usage are given in the article.

Key words: business correspondence, business letter, types of business correspondence, formal styles, business letter language and grammar, business letter clichés, abbreviations, structure and components of business letters, block format, semi-block format, indented format.

Language: English

Citation: Sviatiuk YV (2015) BUSINESS CORRESPONDENCE STYLE AND FORMAT. ISJ Theoretical \& Applied Science 09 (29): 83-88.

Soi: http://s-o-i.org/1.1/TAS-09-29-18 Doi: crossef http://dx.doi.org/10.15863/TAS.2015.09.29.18

\section{Introduction}

Business correspondence is common and widely used in business communication and transactions. Successful and effective business letters assist the flow of information in a company or business environment. Business letters can enhance business contacts, benefit or detriment company performance, and influence the outcomes of negotiations. Effective letter writing is crucial to the success of every company or professional. Therefore, the research of business correspondence language and types is an urgent problem. It is essential to study the rules of business letter writing and single out the peculiarities and specific features of types, styles and structure of business letters.

Business correspondence (business letter) is an umbrella term for all written communication used in business relationships with business partners or for internal communication in the organization. The business correspondence includes all written correspondence in organizations such as personal documents, simple legal documents, personal letters, business contracts, marketing materials and official letters, both in electronic and paper form. Business correspondence includes Information Letters (Letter of Introduction, Letter of Inquiry, Letter of Confirmation, Letter of Notification, Apology Letter), Letters of Business Offer (Letter of Proposal,
Letter of Bid), Letters of Demand (Letter of Request), Letters of Claim or Complaint, Advertising and marketing materials (brochures, leaflets), Personnel Letters (Curriculum Vitae (CV) or Resume, Motivation Letter, Letter of Application, Cover Letter, Letter of Recommendations), Personal and Social Letters (Invitations, Congratulations, Announcements, Condolence Letters).

A distinct and unified idea behind the letter is the first requisite for giving it the hang-together quality and the punch that gets results. The idea cannot be conveyed to the reader unless it is presented logically. He won't get a single general impression from what you are saying to him unless there is unity of thought in the composition. The reader cannot follow the argument unless it has continuity, sequence of thought. And, finally alongside with logic and style, not less attention and efforts should be given to a strong conclusion. These five principles - the idea, logic, unity of thought, continuity, and conclusion - are the forces that hold the letter together and make it effective. These principles are not optional rules or academic theories. They are based on the actual experiences of men ever since they began to talk and write. All forms of communication, including business correspondence, most easily accomplish their purpose of arguing the communicative massage or persuading the other 
man, if these major principles of writing are followed [5].

\section{Style in Business Correspondence}

The official business style is not homogeneous by its nature. It can be related to commercial, legal, administrative, international and social relations. Business speech functions in areas of production, trade, management, law, politics, social activity and international relations. Official business style can exist in written (business correspondence, legal texts, paperwork etc.) or oral forms (meetings, negotiations, interviews, presentations, speeches etc.).

The formal business style can be subdivided into some so-called sub-styles, including legislative, diplomatic, administrative-clerical. It is quite natural that all above mentioned sub-styles have their specific features, communicative forms and language clichés. The specific character of formal business communicative activity and conveyed information require specific structure of business texts. Formal business texts should have clear and unambiguous structure [8]. The paragraphs of business letters tend to be short, some only a sentence long. Business letters are not read the same way as articles, reports, or other literature for detailed information or analysis. Thus, paragraphs over ten lines in business correspondence which require much concentration may not be read carefully or read at all.

To enable the recipient to read the letters more rapidly and to comprehend and remember the important facts or ideas, should be used relatively short paragraphs of between three and eight lines long. In business letters, paragraphs that are made up of only a single sentence are common and perfectly acceptable $[12 ; 16]$. The general recommendation is to analyse the purpose, content, or function of each paragraph of a letters. Any paragraph that covers more than one thing should be rearranged and split it into two paragraphs. If you discover two short separate paragraphs that do the same thing, consider joining them into one.

Each different segment of the discussion - each different topic of the letter - should be placed in its own paragraph. Strategically important information should receive special emphasis in business letters. Information in the first and last lines of paragraphs is read and remembered better. Information given in the middle of long paragraphs is easily overlooked or forgotten altogether. Therefore, important information should be placed in rather noticeable positions. Less significant or positive information should appear in less visible points in the business letters. If some unfavorable or negative things are to be said, a good and acceptable strategy is place them in areas of less emphasis.

Formal business style is characterized by conciseness, laconism and economical use of language means. Together with objective character and credibility of information they are the main requirements of this style. Official written documents cannot contain subjective opinion and emotional words. For formal business way of communication it is typical to use impersonal address, because the statement is usually made on behalf of an organization or officials. Regulation of relations and communication according to strictly defined standards resulted in the emergence of standardized formal speech and business style [5].

\section{Language and Grammar Peculiarities}

There are some other features of business language concerning language and grammar usage. Complex sentences, joined by conjunctions, rather than short sentences, are characteristic for formal business style. Simple but polite style is preferable without unnecessary wordiness, familiarity or slang.

Another important characteristic feature of business correspondence is the usage of passive forms when the doer of the action is insignificant. If it is not necessary to show the performer of the action, we can leave the reader unaware.

Your enquiry is being dealt with.

The order has been confirmed.

In the passive sentence, the grammatical subject receives the focus.

The decision was taken by the committee.

The visiting delegation was met by the vice president.

When we use the passive we can hide the subject or report unconfirmed, speculative information.

The shipment may be delayed.

The full conference programme has not yet been printed.

But, still usage of active forms is acceptable and conventional in business correspondence. Firstly, it is easier to read such type of sentence and secondly, these sentences take less words, thus reading takes less time.

One more thing to be remembered is that the verb must always agree with subject. No matter how many words separate the subject and the verb, make sure they agree. Moreover compound subjects always take a plural verb (e.g. The contract and financial statement are authorized by our CEO).

When an indefinite pronoun is used as the subject of a sentence, it is sometimes difficult to tell whether the pronoun is singular or plural. Some take a singular verb while others take a plural verb.

These indefinite pronouns take a singular verb: anybody, anyone, each, either, everybody, everyone, neither, no one, one, somebody, someone.

These indefinite pronouns take a plural verb: few, many, several. 
With the following indefinite pronouns one must judge from the context of the sentence whether to use a singular or plural verb:

all, any, most, none, some.

$C f$. All of the employees are professional.

All of the money is invested.

Cf. None of the orders were processed.

None of the ledger was saved.

Other universal recommendations to follow while writing business letters: avoid using dangling, unclear modifiers, avoid split infinitives, avoid using clichés and jargon [1, 35-37]. On the whole, it is better to avoid using colloquial language or slang not to sound too familiar and impolite. It is important to get the right tone in the letter. This means that, generally speaking, the writer should aim for a neutral tone, avoiding the pompous language on the one hand and language which is too informal on the other.

Pompous, officious-sounding words should be avoided as well as slang and colloquial phrases. Therefore, watch out for puffed-up, importantsounding language $[2 ; 15,465-470]$ in business letters like:

$$
\begin{aligned}
& \text { aforesaid-named, mentioned above } \\
& \text { arrived enclosed-enclosed with } \\
& \text { as to whether - whether } \\
& \text { due to the fact that-because } \\
& \text { in regard to - concerning } \\
& \text { thereafter - after that }
\end{aligned}
$$

Furthermore, choosing positive language will make our letter well-turned. Business writers and speakers recognize that positive, optimistic people are more open to new ideas and change, than are discouraged, unenthusiastic people. Therefore, such communicators have no opportunity to accentuate the positive. Find positive ways to express bad news in your business letters. Often, business letters must give bad news which should be conveyed in a tactful way. Doing so reduces the chances that business relations with the recipient of the bad news will end. If you have bad news for someone, you need not spill all of it in the first sentence. Thus, negative phrasing should be avoided in business letters. To convey bad news positively some words are better avoided (e.g. cannot, forbid, fail, impossible, refuse, prohibit, restrict, deny, etc.). For the above mentioned reasons, we should pay attention not only to the formality in the letter, but also on aspects which have some emotional influence on the reader

\section{Abbreviations in Business Correspondence}

In business correspondence a number of abbreviations are used, some of which are only suitable for informal communication, some even for electronic communication only (e.g. emoticons). In formal business letters, a clear, formal writing style should be used; however, there exist some instances in which the use of abbreviations is appropriate to save both space and time $[13 ; 15]$.
Formal widely used abbreviations:

$A S A P$ - as soon as possible

attn - attention: to show that a letter is for the attention of a particular person

$c c$ - used on a business letter or e-mail to indicate that a copy of a given letter is being sent to the person mentioned

$c / o$ or $c /$ - care of: used in the address on a letter or parcel that you are sending to someone at another person's house

encl. - enclosed or enclosure: used at the top or bottom of a letter to show that an attachment has been included in the letter

ETA - estimated time of arrival

$F A O$ - for the attention of: written in front of someone's name on a document, letter, or envelope to show that it is intended for them

$F Y I$ - for your information: written on a business letter or e-mail to show that it is being sent to someone for their information only; they are not expected to reply or take any action

$p p$ - on behalf of: written in front of someone's name when you are signing a letter for them

PTO - please turn over: used at the bottom of a page to indicate that there is a second page (informal)

$R E$ - used in business letters to introduce their subject matter

ref. - reference: used in a business letter when you are giving the numbers and letters that show exactly which document or piece of information you are writing about

$R S V P$ - used on written invitations to ask the invited person to confirm their attendance

$T B A$ - to be announced

$T B D$ - to be determined

Other often used abbreviations in business letters:

$a / c-$ account

appar. - apparently

c. or ca. - approximately, about (Latin circa)

$c f$. - compare (Latin confer)

comm.-commerce

Corp. - Corporation

$d t$ - date

e.g. - for example (Latin exampli gratia)

et al. - and other people (Latin et alii)

etc. - and so forth (Latin et cetra)

ibid. - in the same book, chapter, (Latin ibidem)

i.e. - in other words (Latin id est)

Ltd. - Limited

$n b$. - nota bene

$N O O$ - not on original

p. a. - a year, each year (Latin per annum)

p. a. - per head (Latin per capita)

$P \& P$ - postage and packing

$p d d$ - probable date of delivery

PIN - postal index number or Personal Identification Number 
$S A E$ - stamped (self-) addressed envelope $v s$ - against (Latin versus)

ZIP (code) - Zone Improvement Plan (used in US addresses after the state designation to assure delivery)

\section{Letters}

\section{Components and Structure of Business}

Any standard business letter has certain common components and formulas which are recognized and handled accordingly. The number of components may vary significantly depending on the aim of the business letter $[3 ; 7 ; 11 ; 15]$. A basic business letter is composed in three steps: introduction, body of the letter and end remarks.

The introduction block states the reason for writing the letter. The introduction helps the reader understand in which context the letter should be considered. Possibilities include inquiries, demands, business offers, instructions for personnel, business requests, complaints, job inquires and more.

Introduction includes heading, inside address, salutation and subject or reference line.

The heading contains the writer's address and the date of the letter. If letterhead stationery is used the writer's name is not included and only a date is needed in a heading.

The inside address shows the name and address of the recipient of the letter. This information helps prevent confusion. Also, if the recipient has moved, the inside address helps to determine what to do with the letter. In the inside address, include the appropriate title of respect of the recipient; and copy the name of the company exactly as that company writes it.

Another significant issue is salutation in business letters. When you do have the names of individuals, remember to address them appropriately: Mrs., Ms., Mr., Dr., and so on. The salutation, the addressee's name, is followed by a colon. If you don't know whether the recipient is a man or woman, traditionally you write "Dear Sir" or "Dear Sirs". More recently, however, salutations such as "Dear Sir or Madame," "Dear Ladies and Gentlemen" or "Dear Friends" have been recommended. Notice that in the simplified letter format, the salutation line is eliminated altogether. Deleting the salutation line altogether or inserting "To Whom It May Concern" in its place, however, is not always a good solution, it's quite impersonal.

It is advisable to get a person's name within the organization, make a quick, anonymous phone call to get a name. Otherwise it is possible to address the salutation to a department name, committee name, or a position name: "Dear Customer Relations Department," "Dear Recruitment Committee," "Dear Chairperson," "Dear Finance Director".

The subject or reference line may replace the salutation or be included into it. The subject line announces the main business of the letter. If you are responding to a letter, identify that letter by its subject and date in the first paragraph or sentence.

With reference to your advertisement in the Times,

With reference to your letter of $23^{r d}$ March,

With reference to your phone call today,

Thank you for your letter of March $5^{\text {th }}$.

The body of the letter contains the actual message with details about what you would like to accomplish. This section of a business letter is extremely important. This is where you achieve your goals in writing a business letter [1, 35-37]. Therefore, state the main business, purpose or subject matter right away. Let the reader know from the very first sentence what your letter is about using the following phrases.

I am writing to inquire about ...

The reason I am writing is to confirm ...

I would like to comment on ...

I should apologize for ...

Remember that when business people open a letter, their first concern is to know what the letter is about, what its purpose is, and why they must spend their time reading it. Therefore, avoid round-about beginnings. In the first sentence of any main body paragraph of a business letter, try to locate a word or phrase that indicates the topic of that paragraph.

To make sure the main points are done clearly, fully and in a logical sequence it is advisable to priorities the arguments and facts, use conjunctions and link words for cohesion, itemize using lists whenever possible in a business letter. Listing spreads out the text of the letter, making it easier to pick up the important points rapidly. Lists can be handled in several ways using bullet points or other indicators. The link words are used to signal the kind of connection there is between one statement and another. To express contrast, result, emphasis, extra information, sequencing in time can be used the following phrases:

otherwise, apart from that, accordingly, whereas, hence, furthermore, moreover, besides; in addition, thus, consequently, as a consequence, therefore, on the contrary, however, still, in spite of, despite, nevertheless, while, firstly, secondly, next, lastly,

to begin with, I should inform you....

in the beginning..., at the outset......

on the one hand..., on the other hand

to outline, to emphasize, to focus on, to highlight.

Conclusion contains information about intended next steps and actions - what you would like to happen in the future. The writer should provide a call for future action. This can be a chance to talk in person, a follow-up letter or more. It's important to make it clear that you would expect the next step from the person reading your business letter. 
Give your business letter an 'action ending' whenever appropriate. An 'action-ending' makes clear what the writer of the letter expects the recipient to do and when. Ineffective conclusions to business letters often end with rather limp, noncommittal statements such as 'Hope to hear from you soon'. Instead, or in addition, specify the action the recipient should take and the schedule for that action.

At the end of a body section come closing remarks and reference to future contact:

Thank you for your help.

Please contact us again if you have any questions

Please contact us if there are any problems.

Let me know if I can be of any further assistance.

I look forward to hearing from you soon.

I look forward to meeting you next Tuesday.

After the body paragraphs come end remarks including complimentary close, signature block, end notations (enclosures or copies).

The complimentary close is the phrase used after the body of the letter. There are three types of complimentary close: formal, standard and informal. The following phrases can be used with any type of complimentary close:

Sincerely, Sincerely yours, Yours sincerely, In addition, for formal complimentary close are used:

Respectfully, Respectfully yours,

For informal complimentary close are appropriate:

Yours truly, Cordially,

Notice that only the first letter is capitalized, and it is always followed by a comma.

Signature block. Usually, the writer's name is typed four lines below the complimentary close, and signed in between. If the writer is a woman and wants to make her marital status clear, Miss, Ms., or Mrs. are used in parentheses before the typed version of the first name. Whenever possible, the title or the name of the position held should be included just below the name.

Just below the signature block are often several abbreviations or phrases that have important functions and are called end notations (enclosures or copies).

Enclosures. To make sure that the recipient knows that items accompany the letter are in the same envelope, such indications as Enclosure, Encl., Enclosures (2) are used.

Copies. If copies of a letter are sent to others, this fact is indicated among the end notations also. If, for example, a copy is sent to a lawyer, write something like this: $c c$ : $M r$. Raymond Mason, Attorney. It should be noted that ' $c c$ :' is not capitalized and is always followed by a colon.

\section{Formats for Letter Writing}

The format of a piece of writing is the way it is organised and arranged. The format used for a letter is typically determined by the person writing the letter. Sometimes a company will have a house style for a format in which letters must be written, but typically the writer must choose the format $[6 ; 11]$.

The standard formats used for most business letters written today are: the block, semi-block, and indented letter formats $[15,31]$. These three formats can all be used effectively for writing any business letter.

\section{Block}

The block format is sometimes called 'complete block' or 'full block'. In this format, all the lines of the letter, from the dateline to the last notation, are flush with the left margin. Paragraphs are not indented but rather begin flush with the left margin. Single-spacing is used within the paragraphs, and double-spacing between the structure parts of the letter.

The salutation should be typed two lines below the inside address or attention line if there is one. If there is a subject line, it is typed two lines above or below the salutation. The body of the letter begins two lines below the salutation or subject line if there is one. Two lines below the last line of the letter, the complimentary close is typed. The signature block is typed four lines below the complimentary close. An identification line is typed two lines below the signature block. All other notations (e.g., enclosure, distribution) are typed two lines below the identification line.

Semi-block

The semi-block format, sometimes called 'modified block'. This format differs from the block in the position of the dateline (and reference line if there is one) and the complimentary close and signature block. The dateline is usually aligned with the right margin, although sometimes it is centered in relation to the printed letterhead if this presents a more balanced look. The complimentary close and signature block can correctly be placed in any of several locations. Paragraphs are not indented. The spacing of various parts of the semi-block format letter is the same as for the full block format.

The semi-block format is widely used because of the balanced look it gives to a letter. Since everything is flush with the left margin in the full block format, it almost appears as if the letter might tip over to the left. In the semi-block format, since the date, complimentary close, and signature block are toward the right, the letter is balanced in place and not tipped to either side.

\section{Indented format}

The person writing the letter may choose also indented format. In that case all the paragraphs are indented. In the indented format letter, as in the previous formats, various parts begin at the left 
margin, except for the date and the complimentary close and the signature.

\section{Conclusion}

Business correspondence is indispensable part of business communication. To write an effective and successful business letters, arguing and achieving the business objective, it is essential to comprehend the whole range of such things as: occasions on which the particular letter is written, the style of letter, useful and accepted expressions.

The major features of business language are: conciseness, laconism, specific terminology, objective character. Each type of business letter has its own standard phrases and clichés. By using these standard phrases, it is possible to give a professional tone to business letters, effectively reveal the content of the message and achieve business aims. The paragraphs of business letters tend to be short, some only a sentence long.

There are some other features of business correspondence concerning language and grammar: wide usage of passive forms, complex sentences, rather than short sentences. Simple but professional language is preferable without unnecessary wordiness, familiarity or slang.

The number of standard business letter components may vary significantly depending on the aim and situation of business communication and usually includes heading, inside address, salutation and subject or reference line, the body or main part of any business letter, complimentary close, signature block, end notations.

The business letters can be arranged in the block, semi-block, and indented letter formats used for most business correspondence.

\section{References:}

1. Ashley A (2003) Oxford Handbook of Commercial Correspondence. - Oxford: Oxford University Press, 2003. - 304p.

2. Blake $G$ (2015) The 10 deadliest words and phrases in business / G. Blake // Business know-how. Available: http://www.businessknowhow.com/marketing/t endeadliestwords.htm (Accessed: 20.09.2015).

3. Bly R (2004) Webster's New World. Letter Writing Handbook / Robert Bly. - Indianapolis: Wiley Publishing, Inc. - 2004. - 584 p.

4. Borisenko II, Yevtushenko LI, Daineko VV (1999) English in International Documents and Diplomatic Correspondence. - Kyiv: Logos, 1999.

5. (2015) Business Correspondence. - Vol. 1. Available: $\quad$ http://leadership-skills-forlife.com/support-files/businesscorrespondence (Accessed: 20.09.2015).

6. (2004) Business Letters for Busy People. Time saving, ready-to-use letters for any occasion / ed. by John A. Carey. - NJ: Career Press. 2004. - 274p.

7. Bykonya OP (2013) Lingvistychni osoblyvosti dilovogo anglomovnogo pysemnogo movlennya. Available:

http://scaspee.com/6/2013/01/37.html

(Accessed: 20.09.2015).

8. Duckworth M (2003) Business grammar and practice. Oxford: Oxford University Press.

9. Gibson R (2002) Intercultural business communication. Oxford: Oxford University Press.

10. Gillaerts P (2008) Genre Variation in Business Letters: Linguistic Insights. Studies in
Language and Communication Series / P. Gillaerts, M. Gotti. - N.Y.: PeterLang, 2008. $407 \mathrm{p}$.

11. Kotkovets AL (2014) Kompozitsijna struktura movlennevogo zanru "dilovy lyst" / Visnyk natsionalnogo tehnichnogo universytetu Ukrainy "Kyivsky politehnichny instytut". Vypusk 3. - 2014. - pp. $31-36$.

12. Krisanova TA (2009) Leksyko-gramatychni osoblyvosti angliyskogo ta ykraiynskogo dilovogo lysta: komparatyvny aspect / T.A. Krisanova. - Naukovy visnyk Volynskogo natsionalnogo universytetu №17, Filologichni nauky: Movoznavstvo. - Lytsk, 2009. - pp. 31 -34 .

13. Lougheed L (2003) Business Correspondence: A guide to Everyday Writing, Second edition / L. Lougheed. - N.Y.: Pearson Education, 2003. $-149 \mathrm{p}$.

14. Malyuga EN (2012) Professional Language in Formal and Business Style / E. N.Malyuga // Global Journal of Human Social Science. 2012. - Vol. 12. Issue 3. August 2012. - pp. 7 10.

15. Seglin J, Coleman E (2002) The AMA Handbook of Business Letters / J. Seglin, E. Coleman. - [3th ed.]. - N.Y. : AMACOM, 2002. $-514 \mathrm{p}$.

16. Suhanova ID (1984) Kompozitsyonnostrukturnye i lingvostilisticheskie parametry tekstov zhanra kommercheskoj korrespondentzii: dis. ... kand. filol. nauk: 10.02.04 / I.D. Suhanova. - M., 1984. - 241s. 